\title{
Osallistujakeskeisyys aikuiskoulutuksessa
}

Lindroos, Ritva. 1988. Osallistujakeskeisyys aikuiskoulutuksessa. Aikuiskasvatus 8, 4. 26-30. - Artikkelissa käsitellään osallistujakeskeisyyden ongelmaa aikuiskoulutuksessa ja erityisesti työllisyyskoulutuksessa. Avainsanat: osallistujakeskeisyys, koulutuksen legitimiteetti, koulutukseen osallistuminen, opetuksessa osallistuminen.

Tutkimuksessani "Osallistujakeskeisyys aikuiskoulutuksessa - Osallistujakeskeisyyden kommunikatiivista tarkastelua" (Lindroos 1987) olen arvioinut osallistujakeskeisyyden toteutumista 11 TYKO (työelämään ja koulutukseen valmentavilla) -kursseilla neljässä eri ammattikurssikeskuksessa sekä yhdellä akateemisten työttömien urasuunnittelukurssilla.

\section{Osallistujakeskeisyyden määritteet}

Osallistujakeskeisyyttä on tarkasteltu oppimisopetustilanteen tasolla. Tutkimuksessa on arvioitu opettajien toimintaa. Osallistujakeskeisyys on mielletty tutkimuksessa legitimointiperiaatteena. Koulutuksen legitiimisyydellä tarkoitetaan tässä yksimielisyyttä koulutuksen oikeutuksesta ja osallistujakeskeisyydellä legitimointiperiaatteena tapaa turvata tällainen yksimielisyys: mitä tehdään, millaisilla edellytyksillä ja miten menetellen.

Tutkimuksessa kehitellään osallistujakeskeisyyden kriteerejä ja käytetään niitä opetustilanteiden arvioimiseen. Opettajan toiminnan arvioimisessa on kaksi tasoa: toisella opiskelijat arvioivat opettajan toimintaa annetuilla käyttäytymisen kriteereillä (kyselylomake) ja toisella kuvattiin oppimis-opetustilanteen kommunikaatiota (diskurssianalyysi). Oppimis-opetustilanteiden vuorovaikutuksen tarkastelua täydennettiin eräisiin taustamuuttujiin (sukupuoli, ikä, peruskoulutus, ammatillinen koulutus) ja opiskelijoiden opiskelun tavoitteisiin liittyvillä tarkasteluịlla. Tutkimuksessa arvioitiin, liittyykö opiskelijoiden taustoihin joitakin tyypillisiä tapoja arvioida opettajan toimintaa.

\section{Osallistujakeskeisyys TYKO-kOulutuksessa}

Tutkimus (Lindroos 1987) on toiminut tähän mennessä oppimis-opetustilanteen tasolla. Opettajanäkökulman säilyttämiseksi tutkimus rajattiin koskemaan kunkin kurssin osalta ainoastaan yhden opettajan toimintaa ja kaikkien kurssien osalta samalla jaksolla kurssisuunnitelmaa. Opettajan toiminta määriteltiin opiskelijoihin nähden symmetriseksi tai epäsymmetriseksi opetuskommunikaation piirteiden perusteella. - Tavoitteena oli kuvata osallistujakeskeisyyden näkökulmasta ihanteellista oppimis-opetustilannetta.

Tutkimuksen kohderyhmäksi haluttiin alunperin valita koulutusmuoto, jossa pyritään ongelma- ja opiskelijakeskeisyyteen ja jossa julkilausuttuna tavoitteena on kyseiseen koulutukseen osallistumisen kautta tarjota opiskelijoille foorumi kehittää itsenäisiä valmiuksia suunnitella omaa elämäänsä (ja erityisesti työ- ja koulutusuraansa). Koulutuksen didaktisen muodon tulee olla silloin sellaisen, että se sallii opiskelijoiden osallistumisen itseään koskevaan päätöksentekoon ja siten mahdollisuuden harjoitella sosiaalisia taitojaan sekä toisaalta tarjoaa riittävän tiedollisen perustan lisätä itsetuntemustaan ja parantaa yhteiskunnallisen (mm. työhön) osallistumisen tiedollisia valmiuksiaan.

Valitsin tutkimukseni kohteeksi TYKO-koulutuksen, koska se mielestäni täyttää edellä kuvaamani käytännölliset osallistujakeskeisyyden vaatimukset. Tutkimukseni teoreettiset tavoitteet liittyvät eräänlaisen ideaalisen osallistujakeskeisyyden käsitteellistämiseen sellais- 
ten teoreettisten välineiden luomiseksi, joiden avulla TYKO-koulutusta voidaan tarkastella sen omia tavoitteita vasten sekä mahdollisesti kehittää kurssin didaktista käytäntöä.

\section{Legitimointi aikuiskasvatuksessa}

Legitimiteetti sosiologisena käsitteenä tarkoittaa vallankäytön hyväksyksi kokemista, yksimielisyyttä koskien vallankäytön oikeutusta ja vallitsevaa sosiaalista järjestystä (ks. Tietgens 1980, 69). Legitimointi on yritystä saada koulutus näyttämään asianomaisille perustellulta ja järkevältä. Koulutuksen subjektiivinen merkitys luodaan normikasvatuksella. Osallistujan tultua tietoiseksi normeista hän ikään kuin liittyy yhteiseen "kognitiiviseen kulttuuriin". Toiminta tavoitteellistuu, tarkoituksenmukaistuu, optimaalistuu (Mader 1980, 72). Aikuiskasvatus kytkeytyy kolmella tasolla yleisiin legitimointiprosesseihin: aikuiskasvatus legitimoi, aikuiskasvatus itsessään täytyy legitimoida tai aikuiskasvatus edellyttää osallistujilta legitimointia (Tietgens 1980, 72).

Koulutuksesta on tullut tärkeä yhteiskuntapolitiikan väline. Nopeat taloudelliset, tekniset ja sosiaaliset muutokset ovat funktionaalistaneet koulutusjärjestelmän tuotantoelämän ja valtion legitimointitarpeisiin. Von Werder $(1977,57)$ on kutsunut tätä aikuiskasvatuksen funktionaaliseksi paradigmaksi. Tarve vaihtaa ammattia, statusta, identiteettiä edellyttää aikuiskasvatuksen yhteiskunnallistamista (emt., 58 ). Koulutus, joka voi lisätä kasvatuksen kautta yhteiskunnallisten instituutioiden tehokkuutta ja vaikuttavuutta, on yhteiskunnan tarpeiden kannalta ensisijaista (ks. myös Griffin 1983, 219). Ammatillisen aikuiskoulutuksen alueella pyrkivätkin etusijalle nousemaan talouselämän ja tuotannon vaatimuksista ohjautuva työvoimapoliittinen tavoitteenasettelu kasvatuksellisten ja ihmiskeskeisten tavoitteiden kustannuksella (Alanen 1985, 11). Myös Olbrich (1980) toteaa legitimoinnin käsitteen saaneen aikuiskasvatuksessa yhteiskunnallisten asiantilojen turvaamisen merkityksen. Olbrich kuvaa tätä institutionaalisen legitimoinnin termillä. Se sisältää toisaalta jokapäiväisen käytännön sosiaalisen ja poliittisen legitimoinnin sekä aikuiskasvatuksen välineellistämisen yhteiskunnallisten ryhmäintressien ajamiseen, toisaalta normatiivisen tavoitteenasettelun (ks. emt., 8). Aikuiskasvatus on lisääntyvästi "kriisinhallintaa". Poliittis-taloudellisista ongelmista tehdään pedagogisia ongelmia.

Institutionaalinen legitimointi sisältää ajatuksen, että oppija hyväksyy opetuksen ja opetussuunnitelmalliset vaatimukset itsestäänselvyyksinä. Subjektiiviset tarpeet ja motiivit ovat tunnustettavia vain silloin, kun ne voidaan lu- kea yhteiskunnallisiin tarpeisiin (Kokemohr 1982).

Koulutusjärjestelmän on toisaalta kuitenkin voitava olettaa, että arkipäivän normatiivinen orientaatio ohjaa ihmisiä opiskeluun sekä motivoi omien subjektiivisten motiivien muuttamiseen. On voitava myös olettaa, että oppijat kulloinkin tunnustavat opetussuunnitelman, so. että opetussuunnitelma voidaan menestyksellisesti toteuttaa.

Tutkimukseni kohderyhmä "työelämään ja koulutukseen valmentavat" kurssit sekä samankaltaisin tavoittein toiminut akateemisten työttömien "urasuunnittelukurssi" ovat hyvä esimerkki koulutuksesta, jossa yksilön ja yhteiskunnan tarpeet muodostavat ristiriitaisen asetelman. Koska TYKO-koulutus on lain mukaan toisaalta ammatillista aikuiskoulutusta, toisaalta työvoimapoliittinen keino (ks. myös Sihvonen 1980, 6), koulutuksen arvioimisen kriteerit ovat paitsi kasvatukselliset kriteerit myös kursseilta työllistyminen. Opiskelijat tulevat kursseille suunnittelemaan omaa elämäänsä. Opetussuunnitelma (erityisesti TYKO-kursseilla) ohjaa ja rajoittaa kuitenkin opiskelun omasäätöisyyttä.

Jos TYKO-kurssien legitimaatio-ongelmia tarkastellaan oppimisopetustilanteiden ongelmina, eräs ratkaisumahdollisuus on periaatteessa hyväksyä opetussuunnitelma ja kehittää oppimisopetustilanteessa tapahtuvaa opetuksen legitimointia. Legitimaatio-ongelmien tarkastelu siirretään silloin didaktisen teorian tasolle. Esim. (Siebert 1983) on edustanut näkemystä, että opetussuunnitelma tulisi legitimoida itse opetustilanteessa. Ratkaisuksi legitimoinnin ongelmaan on esitetty ns. reflektoivaa didaktiikkaa, jossa opetuksen sisäistä legitimointia etsitään kommunikaatiosta (esim. Behrens \& Buschmayer 1982). Myös omassa tutkimuksessani on paneuduttu legitimaatioongelman kommunikatiiviseen tarkasteluun.

\section{Koonta tutkimustuloksista}

Tutkimuksen kohderyhmän muodostivat 101 TYKO- ja urasuunnittelukurssien opiskelijaa ja kaiken kaikkiaan 6 näiden kurssien opettajaa. Opiskelijoiden opiskelun tavoitteita tutkittiin faktorianalyysillä. Opiskelutavoitteiden eroja suhteessa sukupuoleen, ikään ja koulutukseen tutkittiin yksisuuntaisilla varianssianalyyseillä. Oppimis-opetustilanteiden kommunikaatiota analysoitiin kvalitatiivisella diskurssianalyysillä, jonka käyttö perustui Sagerin (1981) puhetoimintateoreettiseen malliin. Oppimis-opetustilanteiden arviointien eroja sukupuolen, iän, peruskoulutuksen ja ammatillisen koulutuksen suhteen tutkittiin erotteluanalyyseilla.

Opiskelijoiden suorittamien arviointien perusteella voitiin päätellä, että opetus on ollut 
tavallisimmillaan opettajajohtoista. Työskentelytavat ovat olleet ainakin TYKO-kurssilla opettajakeskeisiä. Opiskelijat eivät ole osallistuneet merkittävästi työtapojen suunnitteluun. Osallistujakeskeisyys on toteutunut myönteisenä oppimisilmastona, jossa opiskelijoiden tunteilla ja kokemuksilla on ollut sijansa.

Erotteluanalyysien pohjalta voidaan esittää mm. seuraavia tuloksia: Naiset arvioivat miehiä myönteisemmin opetuksen osallistujakeskeisyyttä. Opettajan kiinnostusta opiskelun hyödyllisyyttä kohtaan sekä kykyä ohjata ryhmän työskentelyä arvioitiin muita kielteisemmin 16-20 -vuotiaiden ryhmässä. Arviointien myönteisyys lisääntyi iän myötä. Opetuksen selkeyttä arvioitiin kielteisemmin peruskouluja lukiokoulutuksen ryhmissä kuin kansakoulutaustan ja oppivelvollisuuskoulun kesken jättäneiden ryhmässä. Mitä vähemmän ammatillista koulutusta sitä hallitsevampana opettajaa pidettiin.

Aikaisemmista tutkimuksista (esim. Siebert 1977 \& al.) tiedetään, että erityisesti negatiivisen oppimistaustan omaavat opiskelijat jättävät didaktiset ratkaisut mieluummin opettajan huoleksi. Kurssityytyväisyyden kannalta osallistumismahdollisuuksia tärkeämpiä ovat kurssilaisten henkilökohtaiset odotukset ja niiden täyttyminen; uskotaan opitun jotakin; opetuksella on ollut selvät tavoitteet; ryhmäilmastoa, opettajaa ja muita osallistujia on pidetty rohkaisevina; opettajalta ja muilta osallistujilta on koettu saadun huomiota; tms.

Opiskelijoilla oli paljon itsetunnon kohottamiseen liittyviä subjektiivisia odotuksia. Suoriutumisen osoittaminen ja itsensä kehittäminen opiskelun tavoitteina liittyivät opettajatoiminnan arviointien myönteisyyteen. Arviointien myönteisyys näytti liittyvän myös naissukupuoleen, ikään (iän kasvaessa myönteisyys kasvoi) ja vähäiseen koulutukseen.

Tulokset ovat samansuuntaisia kuin Ahon (1983) ja Siebertin \& al. (1977) havainnot: Naiset arvioivat opettajan opetustaidon paremmaksi kuin miehet (Aho). Myönteisten arvioiden määrä kasvaa iän myötä (Aho). Kurssityytyväisyys vähenee koulutustason kohoamisen myötä (Siebert \& al.). Myönteisten arvioiden taustalla on usein opiskelu itsensä kehittämisen ja sosiaalisten tavoitteiden vuoksi (Aho).

Opiskelijoiden suorittamat arvioinnit eivät ole pelkästään heidän edustamalleen roolille ominaisia, vaan niitä on arvioitava myös opettajan vaikuttamistapojen perusteella. Myös opettajat luovat opiskelijoille eriytyneitä odotuksia esim. iän, sukupuolen ja koulutuksen mukaisesti. Tässä mielessä myös opettajien havainnot osallistujista voivat olla stereotyyppisiä. Opettajien havaitsemistapojen tutkiminen ei kuitenkaan varsinaisesti sisältynyt tämän tutkimuksen piiriin. Erot eri opettajien kommuni- katiivisessa käyttäytymisessä liittynevät kuitenkin osittain tähän ongelmaan: opettajat ovat toimineet hyvin erilaisissa ryhmissä kullekin ryhmälle ominaisten, eriytyneiden odotusten mukaisesti. Kommunikaation eroissa ei näin olisi välttämättä ollut kyse eri opettajien kohdalla yleistettävistä tavoista kommunikoida, vaan tilannekohtaisten odotusten ohjaamasta toiminnasta, jolloin joissakin tilanteissa toimintaa olisivat ohjanneet esim. opettajajohtoisuuden odotukset. Diskurssianalyysin aineiston vähäisyyden vuoksi ei ollut mahdollista vertailla opetusdiskurssien laadullisia piirteitä saman opettajan eri ryhmissä.

\section{Tulosten pohdiskelua}

TYKO-opiskelijat tulevat kurssille suunnittelemaan ammattiuraansa. TYKO-koulutuksen tavoitteisiin täytyy siis välttämättä sisältyä omaaloitteisuuden ja itsenäisyyden tukeminen. Tästä taasen seuraa, että yhteisopetusjaksolla kuten kurssilla yleensäkin pitäisi suosia osallistujakeskeistä työskentelyä.

Tutkimuksen tulosten valossa näyttäisi siltä, että osallistujilla on erilaiset valmiudet olla omatoimisia ja osallistua. Osaa opiskelijoista pitäisi erityisesti opastaa osallistujakeskeisyyteen. Osallistujakeskeisyyttä sinänsä olisi tarpeen opettaa. Myös opettajia pitäisi koulutuksessaan opastaa analysoimaan itselleen tyypillisiä havaitsemisen ja toiminnan tapoja.

Tutkimuksessani osallistujakeskeisyyden erityisenä määritteenä oli tasa-arvoinen kommunikaatio. Tutkimuksessa käytetyillä käsitteillä voitiin kuvata symmetristä ts. epäsymmetristä kommunikaatiota. Näiltä osin tutkimuksessa kyettiin luomaan eräänlaista metakommunikatiivista kuvausta tietyntyyppisten kommunikatiivisten strategioiden toimivuudesta ts. toimimattomuudesta tasa-arvoisen dialogin näkökulmasta.

Vaikkakaan nimenomaan osallistujakeskeisyyteen ei kuulu jäykkä, ennalta suunniteltu kommunikaatio, opetuksen sisäisen luonteen ymmärtämiseen tarvitaan diagnostisoivia menetelmiä. Onhan käyttäytymisen, myös kielellisen ja kommunikatiivisen, dynamiikka henkilölle itselleen usein tiedostamatonta. Omien kommunikointitapojen ymmärtäminen voi auttaa välttämään kommunikoinnin karikkoja, valitsemaan tietyn tyyppisiä kielellisiä strategioita silloin kun kommunikointi on lukkiutunut, kun haluaa kommunikatiivisesti reflektiivisempää käytäntöä, kun haluaa käynnistää opiskelijoissa reflektoivia prosesseja, kun pyrkii kehittymään suhdekommunikoinnin taidoissa jne. Niinpä voi välttää hallitsevuudesta ja epäsoli- 
daarisuudesta kielivää käyttäytymistä, jos muuten on ilmoittanut olevansa demokraattinen jne. Sagerin (1981) suhdekommunikaation malli on käyttökelpoinen opettajien ja myös opiskelijoiden itsediagnostisoinnin menetelmänä.

Symmetristä kommunikointia olisi tarpeen kehittää edelleen nimenomaan kehittävänä argumentointina, jossa pyrittäisiin tietoisesti opetukseen sisältyvän tiedon, normien, arvojen ja tunteiden ymmärtämiseen. Näin voitaisiin todellistaa sitä, mitä Habermas (1981) tarkoittaa "ideaalisella puhetilanteella". Tutkimuksen kommunikatiivisuustarkastelut tarjoavat perustan jatkaa kommunikaation tutkimista kehittävänä kokeiluna.

\section{Tutkimuksen arviointia}

Opintoryhmän työskentelyn osallistujakeskeisyyden laadun arvioiminen pelkästään ryhmän jäsenten keskinäisen kommunikaation perusteella on ilmeisen kapea näkökulma kuvata osallistujakeskeisyyttä. Osallistujakeskeisyydelle on haettava laajempaa kuvausta. Tämän kuvauksen tulisi ottaa huomioon ensinnäkin, millainen on opiskeluun osallistumisen merkitys yksilölle ja toiseksi, millaiset ovat opiskelijan edellytykset toimia osallistujakeskeisesti oppimis-opetustilanteessa.

Tutkimuksen nykyisessä vaiheessa osallistujakeskeisyyden tarkasteluun on liitetty sisällölliset kysymykset: arvioinnin kohteena ovat opiskelijoiden edellytykset osallistua koulutukseen ja koulutuksessa. Oppimis-opetustilanteissa käyttäytyminen liitetään opiskelijoiden sosialisaatiotaustan tarkasteluun. Opiskelijoiden elämänhistoriallisten taustojen perusteella arvioidaan mm. heidän kielellisiä ja sosiaalisia edellytyksiään osallistua koulutukseen. Tutkimuksessa ollaan kiinnostuneita myös kullekin opiskelijalle ominaisista elämisen säännöistä, kullekin tyypillisistä tavoista muodostaa sosiaalista todellisuuttaan ja tähän liittyen opiskelijoiden omista "käytännöistä", mitä tieto heille merkitsee, esim. miten he hankkivat tietoa joutuessaan ratkomaan arkipäivän ongelmiaan, millainen on arkitiedon ja informaalisen oppimisen suhde tieteelliseen tietoon ja muodolliseen koulutukseen osallistumiseen.

Koulutusvaatimusten yhä lisääntyessä on tarpeen etsiä uusia ratkaisuja koulutukseen osallistumisen/osallistumattomuuden ongelmaan. Perinteinen koulutussosiologinen tutkimus on jo tuonut tietoa eri väestöryhmien osallistumistaipumuksista. Tarvitaan yhä uusia keinoja ihmisten "arkitietoon" vetoamiseksi, jotta he osallistuisivat koulutukseen. Tästä syystä on tarpeen tutkia ihmisten elämän sisäisiä periaatteita, jotta tiedettäisiin, millainen si- säinen merkitys koulutuksella voi yleensä olla erilaisten ihmisten elämässä.

Runsas velvollisuudenomaiseksi koulutukseksi muuttunut aikuiskoulutus (esim. työllisyyskoulutuksessa ja ammatillisessa täydennyskoulutuksessa) on nostamassa esiin toisenkin tyyppisen legitimaatio-ongelman: koulutus muuttuu konfliktialttiimmaksi. Koulutusta on tuskin järkevää järjestää pelkästään sen vuoksi, että erilaiset lait, asetukset, säännöt ja määräykset toteutuisivat. Koulutukseen osallistumisen merkitys on voitava perustella järkevästi. Didaktiset mikroanalyysit eivät tarjoa riittäviä välineitä tämänkaltaisten ongelmien ratkaisemiseen, koska tieto osallistujien yksilöllisistä ja kulttuurisista tulkintamalleista puuttuu.

\section{Kirjallisuus}

Aho, S. 1983. Opiskeluvaikeudet ja opintojen keskeyttäminen kansalais- ja työväenopistoissa. Opintonsa keskeyttäneiden ja loppuunsuorittaneiden opiskelijoiden käsitykset opiskelutavoitteistaan ja -vaikeuksistaan sekä opettajiensa opetustaidosta. Turun yliopiston kasvatustieteiden laitos, julkaisuja A:94.

Alanen, A. 1985. Johdatus aikuiskasvatukseen. Radion aikuiskasvatussarjan ensimmäisen osan oppikirja. Helsinki: Yleisradio.

Behrens, H. \& Buschmeyer, H. 1982. Reflexives Lernen als methodischer und inhaltlicher Anspruch an Lehr- und Lernprozesse mit Erwachsenen. In: Die Hinwendung zum Teilnehmer Signal einer "reflexiven Wende" der Erwachsenenbildung. Beiträge zur Orientierung an der Subjektivität, an der Erfahrung und an Lernproblemen. Universität Bremen. Tagungsberichte Nr. 6.

Habermas, J. 1981. Theorie des kommunikativen Handelns. Bd. 1. Handlungsrationalität und gesellschaftliche Rationalisierung. Frankfurt am Main: Suhrkamp.

Griffin, C. 1983. Social Control, Social Policy and Adult Education. International Journal of Lifelong Education. Vol. 2, Nr. 3/1983, 217-245. London: Taylor \& Francis ltd.

Kokemohr, R. 1982. Kann die "Alltagswende" der Erziehungswissenschaft zur Bearbeitung didaktischer Probleme beitragen? In: D. Lenzen $(\mathrm{Hg})$ Jahrbuch der Erziehungswissenschaft, 19801982. Stuttgart: Klett.

Lindroos, R. 1987. Osallistujakeskeisyys aikuiskoulutuksessa - osallistujakeskeisyyden kommunikatiivista tarkastelua. Lisensiaattitutkimus. Helsingin yliopiston kasvatustieteen laitos.

Mader, W. 1980. Legitimitätsproduktion und sozialpolitische Erwachsenenbildung. In: Olbrich, J. (Hg.) Legitimationsprobleme in der Erwachsenenbildung, 69-86. Stuttgart: Kohlhammer.

Olbrich, J. 1980. Legitimationsprobleme in der Erwachsenenbildung. Stuttgart: W. Kohlhammer.

Sager, S. 1981. Sprache und Beziehung. Linquistische Untersuchungen zum Zusammenhang von sprachlicher Kommunikation und zwischen- 
menschlicher Beziehung. Reihe Germanistische Linquistik 36. Tübingen: Max Niemeyer.

Sihvonen, J. 1980. Työllisyyskoulutus työvoiman uusintamisen keinona. Tampereen yliopisto. Aikuisja nuorisokasvatuksen laitos. Julkaisuja 14/1980.

Siebert, H. (hg.) 1977. Praxis und Forschhung in der Erwachsenenbildung. Opladen: Westdeutscher Verlag.

Siebert, H. .1983. Erwachsenenbildung als Bildungshilfe. Bad Heilbrunn: Klinkhardt.

Tietgens, H. 1980. Zur Legitimationsproblematik der
Erwachsenenbildung als offentliche Aufgabe. In: Olbrich, J. (Hg.) Legitimationsprobleme in der Erwachsenenbildung, 35-68. Stuttgart: Kohlhammer Verlag.

von Werder, L. 1977. Zum Paradigmenwechsel in der Erziehungswissenschaft und der Erwachsenenbildung. Versuch der Konstituierung methodischer und didaktischer Grundlagen der alltäglichen Erwachsenenbildung. In. Dikau, J. \& Holzapfel, G. Didaktik als Ansatzpunkt erwachsenenpädagogischer Theoriebildung. 


\section{AIKUISKASVATUS \\ The Finnish Journal of Adult Education \\ Vol. 8,4/88 \\ ISSN 0358-6197 \\ Summary}

Lindroos, Ritva 1988. Participant centredness in adult education.

- Based on the author's licenciate thesis, the article deals with the problem of participant centredness in adult education and particularly in training of the unemployed.

Keywords: participant centredness, legitimation of training, participating in training, participating in teaching. 